\title{
The history canon project as politics of identity: Renationalizing history education in Denmark
}

\author{
Claus Haas* - Aarhus University, Denmark
}

\begin{abstract}
In 2009, the Danish nation state implemented a history canon, Historie 09, as an obligatory part of the history national curriculum in primary and lower secondary schools. The history canon was part of a high-profile 'cultural battle' that the Danish liberal-conservative political and intellectual elite initiated during the first decade of the twenty-first century - a conflict that also included several other curricular canons. The Danish history curriculum was meant to satisfy three aims: (1) to bolster students with historical cultural ballast as they are prepared to be a part of the globalized economy and community; (2) to revitalize a chronologically structured master narrative about the historical and cultural origins of the Danish nation; and (3) to incorporate history teaching into an ongoing political struggle against some of the possible consequences of increasing cultural and religious diversity in Denmark - and, accordingly, to further a re-traditionalized vision of Denmark as a culturally homogeneous society, presumably existing as distinct from the membership of a heterogeneous European Union. This paper analyses the background of the history canon project in terms of educational policy, how it was realized in the revised history curriculum of 2009, which is still in force, and finally how representatives of the political elite who framed the history canon interpret the history curriculum. I will conclude by briefly discussing how history teachers have responded to the history canon project.
\end{abstract}

Keywords: Denmark; history curriculum; multiculturalism; history canon; politics of identity; diversity; nationalism

\section{Farewell to national identity politics}

In 1996, the Danish historian Søren Mørch published a book entitled Den sidste Danmarkshistorie [The last history of Denmark], subtitled 57 fortællinger af fædrelandets historie [57 tales of the history of the fatherland]. Mørch dealt with two main topics. The first looked at how Denmark became a nation state from around 1830 to the mid-twentieth century. The other examined how subsequently Denmark has slowly ceased to be a nation state. In Mørch's opinion, from the 1950s it was time to say goodbye to the concept of the nation state. The 'ideology-producing forces' of the nation state were increasingly burnt out - for example, the welfare state, political parties, the national church, primary and lower secondary education and the overall education system.

In Mørch's 56th tale 'Nationalstaten' [The nation state], he described the role of schools in developing Danish national consciousness. One of the most essential projects - and perhaps the most essential - of the Danish nation state was to convince the people of Denmark that they were Danish: in other words, to make them feel that they had the most important thing, their Danishness, in common. Danishness was 
something to be explained and learned. Mørch focused on the assimilation of national identity. The supporting elements of the nation state - the notion of a Danish national culture of unity, with a shared language and history - were ideological constructs that only existed as long as the public was willing to invest resources and energy in maintaining them:

This has to be a focal point in what schools should teach to children ... When there is no longer any impetus or desire to invest in persuading schoolteachers to zealously promote the national language, the history and the culture of unity into their pupils - and by that, I mean boxing their ears or using the cane - the construct of 'Denmark', 'our fatherland', as we have perceived it since the 1960s will be no more. Perhaps this does not really matter all that much. It could be said that it has done its bit. (Mørch, 1996: 542-4)

It was not just the nation state that was apparently in decline by the 1960s. The supporting cultural narratives about it were as well; hence the title of Mørch's book, Den sidste Danmarkshistorie [The last history of Denmark]. According to Mørch, things had gone so far not least because teachers had abandoned teaching national history in primary and lower secondary education. Mørch wrote that what was evolving was a multi-ethnic, multicultural society. He did not openly condemn this, but he was absolutely aware that it presented a serious political and sociocultural challenge to Danish identity because 'the political system is unable to work out how to handle the situation' (ibid.: 398). This explains why the entire final third of Den sidste Danmarkshistorie was about 'how difficult it is to decide what should happen to Denmark that is making the transition from a nation state to a multicultural society' (ibid.). Mørch was absolutely right about the latter, that is, multiculturalism. However, what both he and I did not anticipate in 1996 were the ways in which the Danish nation state would try to revitalize national history education during the first decade of the twenty-first century - the main theme of this article.

\section{The focuses of this article}

The first focus of this article is on how and why the Danish nation implemented a mandatory history canon as a part of a reformed history curriculum in 2009, entitled Fælles Mål 2009. Historie. Faghæfte 4 [Common goals 2009. History. Subject book 4] below called Historie 09 - that is still in force. Second, I focus on aspects of the political context for this initiative, and draw attention to ways in which we should understand Historie 09 and its Danish history canon as expressions of national identity politics. (For a definition of this term, see below.) Third, I will further discuss issues of identity politics, from the content of the history canon itself and from the ways in which leading Danish politicians have interpreted the canon and Historie 09. Specifically, I am interested in clarifying how Historie 09 dealt with the national-multicultural schism and how leading politicians interpreted it as it was implemented.

I interpret the construction and implementation of a national history curriculum as acts of identity politics: something that Søren Mørch also described, although without using the term 'identity politics'. The term is often used in connection with the political mobilization of new social movements that emerged from the 1960s and the decades afterwards - that is, women's and minority movements of different kinds related, for example, to issues of race, ethnicity, sexuality and disability (Calhoun, 1995; Benhabib, 2002; Bernstein, 2005; Castells, 1997; Haas, 2014; Hall, 1992; Jensen, 2004; 
Elliott, 2011). Here, I use the concept of identity politics more broadly and inclusively to refer to the historical-social processes through which agents try to further or impede the construction of identities of individuals and groups of people, for instance through history education. Understood in this inclusive way, identity politics refers to traditions, which are as old as the construction of the modern nation state and the Danish public school system. The French sociologist Bourdieu (1998: 45-6) pinpoints the relationship between the state and its proselytization of national identity:

Through classification systems inscribed in law, through bureaucratic structures, educational structures and social rituals ... the state molds mental structures and imposes common principles of vision and division, of thinking that are to be the civilized mind ... And it thereby contributes to the construction of what is commonly designated as national identity ... By universally imposing and inculcating a dominant culture thus constituted a legitimate culture, the school system through the teaching of history ... inculcates the foundation of a true 'civil religion' and more precisely, the fundamental presuppositions of the national self-image.

In Denmark, the history canon of 2009 was created as an integrated part of a much more comprehensive state-monitored canon-policy programme, including a canon of Danish literature (2004), a culture canon (2006), a democracy canon (2008), a nature canon (2009) and a Denmark's canon - a comprehensive set of values for the future society (2016). This article only deals with the history canon.

\section{History education as globalized identity politics}

Since the 1970s, the Danish nation state has revised the national history curriculum for primary and lower secondary schools more often than other school subjects: in 1974, 1977, 1984, 1995, 2002, 2004 and 2009. This is a clear indication that the Danish political establishment considers that history education is a central component in state-regulated 'politics of identity'.

A national history curriculum includes both prescriptive (binding) and nonbinding elements. The objectives of history teaching - referred to recently as the key knowledge and skills areas, along with attainment objectives and final targets - are prescribed. Consultative elements of the curricula are non-prescriptive. While the Danish National Education Act established the formal legal framework for schools, municipal school authorities approve the school curricula that school boards propose, but in compliance with national legislation for the framework and mission statement for primary and lower secondary education. However, in practice, the Ministry of Education's curricula for all school subjects generally constitute the only directional model for municipalities, school boards and teachers.

Following its election victory in 2005, the liberal-conservative government began a political process that led to the 2009 revised national history curriculum. This process commenced with the Nye mål [New objectives] government programme in February that year. The following year it included the title Historiefaget skal styrkes [History to be strengthened]:

The Government wishes to ensure that Years 4 and 5 have an extra hour in which to work on history. In an increasingly globalized world, it is crucial for all Danish children to have a robust knowledge of history and Danish cultural heritage. (Regeringen, 2005b: 16) 
The Danish government programme also announced the establishment of a Globalization Council. Prime Minister Anders Fogh Rasmussen appointed himself the chairman of this council, an indication that the work of the council was of high priority. The council's mandate was to provide guidance to the government on how the country would become a leading knowledge society and on the creation of worldclass education (Regeringen, 2005a). Denmark was to be geared up to cope with the global economy. Besides the prime minister, the council included four of his ministers, directors of a number of major business organizations, the director of the national bank, a number of university professors and top managers in business, and trade unionists.

In August 2005, the Danish government produced a White Paper, Verdens bedste folkeskole - vision og strategi [The world's best primary and lower secondary education - vision and strategy], for the Globalization Council to discuss (Verdens bedste folkeskole - vision og strategi (Danmark i den globale økonomi); Regeringen, 2005c). The White Paper looked at schools policy, and how children and young people in primary and lower secondary education, and the Danish nation state of the future, could be equipped to cope with global enterprise and competition. According to the government, the setting of higher, appropriate professional and curricular standards in schools was required for creating world-class Danish primary and secondary education as the current standards, commitments and obligations of the school system were far from sufficient if the government's globalizing ambitions were to be met:

- Basic skills must be reinforced.

- The subject of history must help to familiarize students with Danish culture and give them a knowledge of other cultures so that they can actively participate in the wider world.

- History as a school subject must be strengthened, with additional hours in Years 4 and 5.

- The history curriculum must ... specify descriptions of significant topics and historical periods in chronological order. A history canon will also be introduced. (Regeringen, 2005c: 11)

Students were to be equipped to become part of the Danish nation state's globalized, economic-strategic approach. However, it seemed that there were limits to prescription concerning students' global and European cultural identity. Through a history canon the national history curriculum was only to provide students with the historical and cultural knowledge they needed to develop their Danish identity. In April 2006, the government published more joint results of the high-profile partnership with the Globalization Council in its report Fremgang, fornyelse og tryghed [Success, renewal and security]. Denmark was to be 'one of the best countries in which to live and work - in 10 and 20 years' time as well'. This required strong 'competitiveness and cohesion' (Regeringen, 2006: 6). The ambitions on behalf of primary and lower secondary education took on a key position in the strategy. One consistent theme in this regard was the demand that 'young people should become better at languages and have a greater insight into other cultures' (ibid.: 8). At this point, the globalized visions indicated a double-edged notion of identity politics: both the strengthening of national history and culture, and an aim to further students' awareness of other cultures. In that respect, on the surface of it, it seemed that the government's initiative was positively confronting the national-multicultural schism mentioned above, even though there was no indication of what comprised young people's lack of insight into other cultures, let alone what these other cultures could be. 
Moreover, the Danish government repeated its intention to increase the minimum number of hours of history lessons for Years 4 to 6 from 120 to 180 hours in total. Again, it emphasized, 'This will help to familiarize students with Danish culture and give them a knowledge of other cultures' (ibid.: 14). Some of these words and phrases were repeated when the government promised a more general school reform later the same year, with support from other political parties:

Primary and lower secondary education must work in partnership with parents to provide students with knowledge and skills that prepare them for further education/training and give them a desire to learn more, familiarize them with Danish culture and history, give them an understanding of other countries and cultures, help them to understand human interaction with nature and promote the general development of each individual student. (ibid.: 14)

\section{Canonized identity politics}

With distinguished professor of history and Historiographer Royal, Knud J.V. Jespersen, as its chair, the government Committee for Reinforcing History in Primary and Lower Secondary Education began work in March 2006 (Undervisningsministeriet, 2006). The committee faced a major, problematic task. Particularly powerful members of the Danish nation state's political, cultural, economic and academic elite agreed that the familiarity of children and young people with 'Danish cultural heritage' and their 'understanding of other cultures' were not the only things on the agenda. History teaching was also seen as a key element in the optimization of the Danish nation state's economic ability and social cohesion in a globalized world. The committee's task was made more onerous when its terms of reference (mandate) of 16 January indicated that students' awareness of national history was poor, as was their understanding and appreciation of Danish cultural heritage:

The Government wants history teaching to give students a chronological overview of events, developments and changes that form part of the shared cultural foundation of the people of Denmark. Teaching content must cover all essential topics and periods throughout this time. In the opinion of the Government, primary and lower secondary students are not sufficiently familiar with tales from Danish history and they do not have sufficient knowledge of the history of other nations. (ibid.: 3)

In its report, the committee addressed many facets of history teaching, including notions on its progression, scope and processes, objectives, knowledge and skills, and processes and chronological overview. However, there was one initiative that overshadowed all the others - the committee's reference to the history canon that the government had promised. Because of this, the committee then became known simply as the 'Canon Committee'.

The Canon Committee's history canon had 29 points (see below). A number of specific points put into practice the government's general identity politics - to promote familiarity with Danish culture and an understanding of other cultures. The government intended schools to teach the points as a mandatory element of their curricula. The Canon Committee stated that its history canon's list of events was an integral part of the overall historical learning process: 'the canon points represent significant breaches and changes, or [they] have a symbolic value providing clear signals on content and opportunities for gaining perspectives' (ibid.: 6). 
It was also thought that the canon should be dynamic, that is, that it could be reviewed to reflect changes in the national perspective. However, there was no explanation of why the selected canon points were suitable to promote a solid knowledge of 'Danish cultural heritage' in school students, of what the Canon Committee considered were its characteristics, or of how to perceive the canon's content as having symbolic value in induction into Denmark's cultural heritage. The omission of this specification may be explained by the Canon Committee recommendation that:

The history canon takes into account the fact that various political and cultural groupings in the community must perceive that the list of canon points also represents their own views of Danish history. (ibid.: 6)

The committee's recommendation could be interpreted to indicate that familiarity with Danish culture and history should go hand-in-hand with multicultural identity politics as an understanding of other cultures - a preferred approach. The committee consequently supported a multicultural element - 'the various cultural groupings in the community' - as being integral and key for incorporation both in the history canon and in a forthcoming national history textbook. The question then arose as to whether these recommendations of the Canon Committee would be included in the revision of the national history curriculum.

\section{Monocultural identity politics}

The new history curriculum was implemented in 2009. This was based on the work of a new committee, which was also chaired by Knud J.V. Jespersen. The overall objective of history education in the revised curriculum was:

The teaching must familiarize students with Danish culture and history - cf. the mission statement in the Education Act ... By working on development and contexts from a historical perspective, students will develop their insight into human lives and living conditions through the ages. This will help them to develop their knowledge and understanding of, and attitudes towards, their own culture, other cultures and human interaction with nature. This teaching will give students the opportunity to gain an overview of, and more in-depth knowledge of, historical fields, and reinforce their insight into continuity and change. (Undervisningsministeriet, 2009: 4)

Again, the national-multicultural axis referred to previously was incorporated in the new objectives for history teaching. It is also worth noting that a decision had been made to use Danish culture in an indefinite form, not as 'the Danish cultural heritage', as it was phrased in the history Canon Committee's mandate of 2006. This was possibly an attempt to avoid an essentialist view of what constitutes Danish history and culture. The emphasis of the objective points in this direction - towards a multicultural perspective. The 2009 curriculum Historie 09 refers not only to 'other cultures', but also to 'own culture' in a way that is so imprecise that it might indicate an inclusive and multicultural approach to national history. In this perspective, it makes sense that a specific national perspective of history education is approached through vague formulations later in the 2009 curriculum guidelines:

The terms Denmark and Danish history can be perceived in a number of ways. These varying understandings are incorporated in teaching. For example, it is possible to work with Denmark as a nation state ... Denmark can also be perceived as a nation, i.e. as a people with a community defined 
by a shared language, history, traditions and values. Finally, it is possible to refer to Denmark's historically changing geographical boundaries. Danish society exists and develops in interaction with other states and other cultures. Therefore, most Danish major changes and social conditions over time must be viewed in the context of its history in conjunction with those of other countries. (ibid.: 23)

'It is possible' to work with Denmark as a nation state, and Denmark 'can' be perceived as a nation defined by a shared language, history, traditions and values. Was this a way of indicating that the multicultural recommendation from the Canon Committee had been noted, and that the histories of various cultural groups were to be represented in the canon? Was a multicultural perspective incorporated into the 29 points of the history canon? These points were:

1. The Ertebølle culture (hunters and gatherers 5400 BCE-3900 BCE)

2. Tutankhamun

3. The Sun Chariot

4. Caesar Augustus

5. The Jelling stones (950)

6. King Absalon (1128)

7. The Kalmar Union (14th century)

8. Columbus

9. The Reformation (16th century)

10. King Christian IV (1588-1648)

11. The Peace of Westphalia

12. The coup d'état of 1660

13. The abolition of the 'stavnsbånd' (1788)

14. The storming of the Bastille

15. The abolition of the slave trade (1792/1803)
16. The bombardment of Copenhagen (1801)

17. The Danish Constitution (1849)

18. The Battle of Dybbol (1864)

19. The Battle of Fælleden (1872)

20. The system shift of 1901

21. Women's suffrage (1915)

22. The Reunification (1920)

23. The Kanslergade Agreement (1933)

24. The August uprising and the rescue of the Jews (1943)

25. The UN's Universal Declaration of Human Rights

26. The 1973 energy crisis

27. The fall of the Berlin wall

28. Maastricht election (1992)

29. 11 September 2001

As the italicized titles of most of the history canon's points reveal, holistically the canon was a traditional national Danish master narrative. It is extremely difficult to judge whether some of the canon's points express a multicultural approach to history education. The first point, 'the Ertebølle culture', covers 5400 BCE to 3900 BCE, and the 'Tutankhamun' section mentions the riverine valley culture of Egypt of the Pharaohs in the fifteenth century BCE (ibid.: 24). The section 'Caesar Augustus' refers to the 'heritage of the Roman Empire from the river valley cultures and the Greeks' (ibid.: 28). Of course, these sections may promote understanding of other cultures. But whether these points represent cultural groups in the Denmark of today is highly dubious, just as it is dubious that this was actually what was intended when selecting precisely these topics as elements in a historical master narrative of national identity.

The section on 'The abolition of the slave trade' could also be a reference to a multicultural perspective, since it refers to 'debasement of some classes and people' (ibid.: 28). However, there is no indication of whether this also applies to groups or people past or present in the Danish nation state, for example in the form of racism against black people or other groups in Danish society. A multicultural perspective is also a possibility in the section entitled 'The Battle of Dybbøl (1864)', which marked the end of the civil war in Denmark, and the loss of the German duchies, and hence also the large German-speaking cultural minority, to Prussia. This includes 'minorities in Europe' 
and 'identity and Danishness' (ibid.: 3). The curriculum guidelines also claimed that 'the defeat left the Danish nation state with no foreign minorities' (ibid.: 30). However, this is only correct if we do not include the people of Iceland, Greenland and the Faroe Islands, for instance, who continued to be a part of the post-1864 diminished Danish nation state. One may wonder about the fact that the history of these islands and their people is not mentioned at any point in the history canon or in the national curriculum for history, Historie 09. This would have been an obvious opportunity to show that Danish cultural heritage both past and present is a generally complex and multicultural phenomenon. The section entitled 'The Reunification' provides a little more clarification - albeit in a somewhat reversed manner - as to why this does not happen. It is argued that the loss of Southern Schleswig, in 1864, 'affected Danish self-understanding' and that the event 'puts Danishness under foreign rule into perspective' (ibid.: 31). Specific singular forms are used here, such as the 'Danish self-understanding' and 'Danishness'.

Historie 09 comes across as a deeply divided document. At first glance, it invites an open, inclusive, multicultural understanding of Danish culture and history. However, in reality, multicultural aspects of Danish history have only peripheral significance, or, as the most significant feature of the Historie 09 , it is ignored. The most striking expression of the latter is the fact that the people of Greenland, the Faroe Islands and Iceland are completely neglected in the canon and in the history curriculum as a whole, even though these minorities represent cultures that have been, and continue to be, a key and integral part of the history of the Danish nation state and Danish cultural heritage. Consequently, it comes as no surprise that ethnic and religious minorities arising over the past few decades as a consequence of immigration are completely missing from the canon, and from Historie 09 overall. The multicultural intentions formulated by the Canon Committee in 2006, which stated that 'the canon takes into account the fact that various political and cultural groupings of the society must perceive that the list of canon points also represents their history' (Undervisningsministeriet, 2006: 6), was ignored.

\section{Advancement of identity politics by the political elite}

However, is this analysis sustained if we question the thinking of the Danish politicians involved? We got the opportunity to gain insight into this in 2010 when the Association of Teachers of History and Social Studies in Denmark published a special issue of its journal Historie \& samfund [History and Society]. Bertel Haarder of the party Venstre (the Liberal Party of Denmark), himself Minister of Education in 2006, and in that respect the ideological midwife of the history canon, Søren Krarup of the Danish People's Party, and Christine Antorini of the Social Democrats were invited to comment on the new curriculum. In other words, a government representative and two supporters of the 2009 school reform were to make known their views on history education.

Bertel Haarder (2010: 5) stated that history teaching should not be understood as 'a barrier', but as 'a trampoline' that provides the impetus to allow us 'to understand ourselves and other cultures':

This teaching must arouse students' interest in the culture and history that is part of ourselves that is enshrined in books, pictures, buildings, music and art. History must not glorify or condemn. First and foremost, it must tell us who we are and why Danish society - and our relationship with other countries and cultures - has become what it is ... The previously stated objective was that students should be familiarized with Danish culture. Now it states that primary and lower secondary education should 
familiarize themselves with Danish culture and history. In reality, these are two sides of the same coin, as a knowledge of one's own culture requires the historical knowledge of what this culture emerged from.

Haarder confirmed that the history curriculum of 2009 was part of a project of national identity politics, which did not include a multicultural element. It is all about 'us' - 'it' should tell 'us' who 'we' are. This was why Haarder also used definite forms of terms such as 'culture' and 'history'. The term in the objective - 'one's own culture' to be found in the curriculum guidelines - should not be perceived as a multicultural element. Haarder adopted 'one's own culture' simply to be the same as 'culture' - that is, the national cultural heritage of the ethnic Danes. Haarder noted that he had had some objections to the composition of the history canon. Some key events in 'our history' had not been included. But, despite that, he was satisfied. He said nothing about the absence of the multicultural aspect. Haarder has also expressed his perception of history teaching in this way:

Teaching history is a way of describing destiny. History is all about the self-understanding of various peoples. Hence, history teaching must also include mythological material from ancient times, and particular emphasis should be placed on the events that have helped to define us as a people. ... We followers of Grundtvig [priest, poet and politician (1763-1872)] have always viewed the national identity as not only a way, but as the only way to the universal identity. There is no abstract humanity. All humanity has a national formulation. The only way in which to become a whole human is by knowing the culture in which one has grown up. (Aagard, 2005: n.p.)

Haarder's perception of history teaching can best be understood as what the political elite understands by national identity. According to this understanding, the nation is not a historical-social and political construct. National identity is something universal, an immanent and mythical element in human existence per se. When national identity is not sufficiently applicable - among primary and lower secondary students, for example - this is not due to the fact that national identity does not exist, or that it is not important to them. Rather, a national identity may slumber beneath the historicalsocial reality in which people have to live and work. Therefore, the aim of history teaching is to awaken the latent universal identity - national identity - and reactivate it as a cultural force by influencing awareness of history among school students.

Søren Krarup MP, representing the right-wing Danish People's Party, added to Haarder's views. However, his nationalist approach was, if anything, even more fundamental and essentialist:

The situation is that your history is something you have. That is the starting point. You may be tired of it. You may even be upset about it ... History is not something we choose ourselves. But as a person who exists, one is chosen by one's history and has to live with it - for better or for worse. This is why there is reason to emphasize the fact. People do not choose their own context. Instead, they are placed in fairly specific contexts by being children of their age, a creature of their time, the children of their fathers and mothers, the sons and daughters of their country and their people. (Krarup, 2010: 13)

Here, belonging to the Danish nation is not up for discussion, because people are chosen by their history; it is almost a compulsory biological essence of human existence. 
Just as it is not possible to choose one's own parents, it is not possible to choose to be - or opt out of being - a son or daughter of the Danish people. Krarup considered attempting to do so to be meaningless. However, he was not entirely satisfied with the history canon. Previous falsification of the reality of history and history teaching was approached insufficiently. Schools had been promoting students' 'historylessness' since the 1960s (Krarup, 2010: 13). Bertel Haarder and others had to face the fact that the consequences of 'decades of falsification of the reality of history and the subject in schools' was still just around the corner (ibid.).

Christine Antorini, chair of education policy for the Social Democrats, was also familiar with Krarup's and Haarder's nationalistic ambitions on behalf of history teaching. She agreed that discussion on the objectives of schools and history teaching had to involve a struggle for values and culture. She also agreed 'that it is important to know one's roots' (Antorini, 2010: 11). That said, she disagreed with them on two points. On the one hand, she was sceptical about the ongoing trials involving state control of teaching. She was of the opinion that this involved totalitarian elements. She was linked with another community of memory when making a reference to 'the special cultural repository in Denmark' (ibid.). For this purpose, she highlighted words from the objectives of primary and lower secondary education, stating that schools 'are characterized by intellectual liberty, equality and democracy in everything they do' (ibid.):

These are core cultural values that are found in the Danish Constitution ... If there are any particularly Danish values, they are to be found in the Constitution. No, the fathers of the Constitution were largely inspired by the European thinkers on information and the rights of citizens. The Danish Constitution is not one of the first, best or clearest constitutional documents adopted in the 19th century, nor is it particularly Danish. We have borrowed most principles and values from the constitutions of other countries. (ibid.)

Antorini argued in favour of a non-national, non-state-controlled democratic history curriculum, which neither Krarup nor Haarder mentioned. The consequence of a democratic history curriculum and identity politics must be that Haarder's national essentialism and Krarup's quasi-biological determinism must be rejected. I am with Antorini thus far. However, she did have one thing in common with Haarder and Krarup. Like them, she beat about the bush: does a denationalized and democratic history curriculum also imply a multicultural identity politics? Is the absence of multicultural Denmark in Historie 09 in accordance with the demands of equality and democracy? It is not, I would suggest. But, at this point it is necessary to note one detail that Antorini did not mention. In former history curricula, it was stated that history teaching should strengthen students' motivation for participation in a democratic society. In Historie 09, references to democratic considerations are removed from the objectives, and added to the non-obligatory teaching guide.

\section{Conclusion}

The revised history curriculum - Historie 09- was part of the globalized socio-economic strategic ambitions of the Danish political elite. In some sense, it included both national and multicultural aspects of identity politics, even though very vaguely formulated, so as 'to familiarize students with Danish culture and give them a knowledge of other cultures'. The same point can be made if one includes some general formulations from 
the curriculum guidelines. However, if one also includes the mandatory component of the curriculum - the history canon - it is obvious that Historie 09 is a nation statemonitored attempt to revitalize a chronologically structured master narrative about the historical origins of the ethnic Danes. In this perspective, the history canon can be interpreted is a state-sanctioned way to renationalize the collective identity of students and teachers - and eventually of the population as a whole. Consequently, a multicultural approach, or understanding of Denmark as an imagined community, is absent.

What is left is a monocultural national identity politics. This is no accident, if we look at ways influential Danish politicians interpret the aims of history teaching. The fact that Denmark is, and will continue to constitute, a multicultural polity was completely ignored, and this was perhaps precisely the point that the government wished to emphasize with its history canon project. In that perspective, it makes sense that the histories of the people of Greenland and the Faroe Islands, and the histories of immigrant groups, were not mentioned in either Historie 09 or the canon.

It is worth noting that Christine Antorini, the Social Democrat mentioned above, who was Minister of Education herself between 2011 and 2015, proposed that the mandatory status of the history canon ought to be cancelled. It sparked off a heated debate in the Danish parliament. A majority of the parliament rejected Antorini's proposal. Axel Ahrendtsen, of the Danish People's Party, presented arguments for the rejection.

Traditionally, Danish teachers have had a lot of freedom because the country has been very homogeneous - nationally and culturally. This has been a matter of fact that was not in question. From the 1960s, this changed significantly: first, due to the movement of reform pedagogy and the crusade by the socialists against Bildung (the conception of education as a lifelong learning process, rather than training in formal skills), and later on, as part of the cultural-radicals' death march towards multiculturalism. The thought that Denmark was a home for the Danes, and that school should give the student a feeling of being part of a spiritual and historical community, has been under attack from a minority that has found its way into key positions within the Ministry of Education. Gradually the school curriculum was emptied of national content. Luckily, the voters wanted things to be different. In 2001, they explicitly stopped this dismantling. A broad majority stood behind the restoration of the school's role in identity politics, and thus the implementation of the canons. It tells us quite a lot about Denmark that the history canon's list of points caused so much uproar. Shared culture was an embarrassment to those who were dreaming about multiculturalism. The canon's list destroyed the dream, the illusion (Ahrendtsen et al., 2012).

This and other reactions to Antorini's proposal revealed that the history canon - and the other canons mentioned in the introduction - were part of a much more comprehensive struggle against the development of a multicultural society, a resistance that still constitutes the hegemonic situation in Danish political culture. Whether this monocultural project will succeed remains to be seen.

Ultimately, it will be up to history teachers to bring it to fruition. However, what we do know is that most textbooks for primary and lower secondary schooling follow the history canon, both structurally and substantially. In that sense, the politics of national identity is a success. If one asks teachers, as I have done by the use of semi-structured interviews, the conclusions are ambivalent (Haas, 2014):

- Some teachers seem to be perplexed or unaware of the fact that the history canon is intended as a means to further identity politics. 
- Other teachers seem to reproduce the national master narrative of the history canon more or less uncritically.

- For yet other teachers, multicultural didactical thinking and identity politics are gradually having an impact on their teaching, which means that they to some extent question the relevance and legitimacy of monocultural history education.

In terms of identity politics, these conflicting tendencies probably are expressions of the fact that teachers are fundamentally divided when it comes to handling the nationalmulticultural schisms. In that sense, for some, the history curriculum, teachers' history didactic - and its related politics of identity - to some extend and reflect controversies and conflicts that shape late-modern political culture in Denmark and in many other countries.

\section{Notes on the contributor}

Claus Haas is an associate professor at the Institute of Education, Aarhus University, Denmark. His research areas include didactics of history and civics, public history and popular culture, history culture and the uses of the past, historical consciousness and Europe as a collective narrative, identity politics, multiculturalism, citizenship theory and education, and democratic education.

\section{References}

Aagaard, L.H. (2005) 'Overlæreren'. Berlingske Tidende, 20 May.

Ahrendtsen, A., Flydtkjær, D., Henriksen, M. and Krarup, M. (2012) 'Om kanonlister i undervisningen'. Online. www.ft.dk/samling/20111/forespoergsel/f16/beh1/6/forhandling. htm?startltem=\#nav (accessed 31 July 2018).

Antorini, C. (2010) 'Hvor langt skal politikerne blande sig i kampen om sandheden?'. Historie \& Samfundsfag, 1, March, 10-12.

Benhabib, S. (2002) The Claims of Culture: Equality and diversity in the global era. Princeton: Princeton University Press.

Bernstein, M. (2005) 'Identity politics'. Annual Review of Sociology, 31, 47-74.

Bourdieu. P. (1998) Practical Reason. Cambridge: Polity Press.

Calhoun, C. (1995) Critical Social Theory: Culture, history, and the challenge of difference. Cambridge, MA: Blackwell.

Castells, M. (1997) The Power of Identity. Oxford: Blackwell.

Elliott, A. (2011) 'Editor's introduction'. In Elliott, A. (ed.) Routledge Handbook of Identity Studies. London: Routledge, xii-xxiv.

Haarder, B. (2010) 'Derfor mere historie i skolen'. Historie \& Samfundsfag, 1, March, 5-9.

Haas, C. (2014) Staten, eliten og "os": Erindrings- og identitetspolitik mellem assimilation og livet i salatskålen. Aarhus: Aarhus Universitetsforlag.

Hall, S. (1992) 'The question of cultural identity'. In Hall, S., Held, D. and McGrew, T. (eds) Modernity and its Futures. Cambridge: Polity Press in association with the Open University.

Jensen, B.E. (2004) 'At føre identitetspolitik i et demokrati: en problemudredning'. In Korsgaard, O. (ed.). Medborgerskab, identitet og demokratisk dannelse. Copenhagen: Danmarks Pædagogiske Universitetsforlag.

Krarup, S. (2010) 'Historie - det vigtigste af alle fag'. Historie \& Samfundsfag, 1 March, 13-15.

Mørch, S. (1996) Den sidste Danmarkshistorie: 57 fortællinger af fædrelandets historie. Copenhagen: Gyldendal.

Regeringen (2005a) Danmark og Globaliseringen Regeringen: Debatpjece om globaliseringens udfordringer for Danmark. Online. www.stm.dk/multimedia/Danmark_og_globaliseringen.pdf (accessed 31 July 2018).

Regeringen (2005b) Nye mål. Government programme: VK-regeringen II. Online. www.regeringen. dk/tidligere-regeringsgrundlag/nye-maal/ (accessed 31 July 2018).

Regeringen (2005c) Verdens bedste folkeskole - vision og strategi (Danmark i den globale økonomi). Online. www.stm.dk/multimedia/Debatopl_g_folkeskole.pdf (accessed 29 June 2018). 
Regeringen (2006) Fremgang, fornyelse og tryghed: Strategi for Danmark i den globale økonomi. Copenhagen: Regeringen.

Undervisningsministeriet (2006) Rapport fra udvalget til styrkelse af historie i folkeskolen. Copenhagen: Undervisningsministeriet.

Undervisningsministeriet (2009) Fælles mål 2009 - historie (Faghæfte 4). Copenhagen: Undervisningsministeriet. 